\title{
Oral Language Proficiency: Basis for Material Design and Development
}

\author{
Jonrey Y. Torrevillas, MEd-LT \\ The University of Mindanao, Philippines \\ Email: reyjon1992@gmail.com \\ DOI: http://doi.org/ 10.36892/ijlls.v4i1.749
}

$\begin{array}{ll}\text { Received: } & \text { Abstract } \\ \text { 12/11/2021 } & \text { This study examined the perceived level of oral language proficiency of the freshmen } \\ & \text { college students enrolled in the purposive communication course during the school } \\ \text { Accepted: } & \text { year 2019-2020 in a private university of Davao City. It also aimed to determine the } \\ & \text { challenges experienced in speaking activities. This study used embedded mixed-method } \\ & \text { design. An adopted survey questionnaire was used in quantitative that contained six } \\ & \text { constructs: comprehension, fluency, vocabulary, pronunciation, grammar, and non- } \\ \text { Keywords: } & \text { verbal communication. Whereas, in qualitative data, it employed focus group } \\ \text { proficiency, } & \text { discussion. Sixty respondents participated in quantitative data selected through simple } \\ \text { speaking } & \text { random sampling, and eight respondents participated in interview sessions. Results } \\ \text { challenges, } & \text { reveal that: (a) students overall perceived level of their oral language proficiency is } \\ \text { embedded } & \text { high; } \text { (b) the themes that flourished in the FGD are dilemmas in comprehending the } \\ \text { mixed-methods } & \text { subject matter/topic, drawbacks in analyzing the question, troubles in organizing } \\ \text { design } & \text { thoughts and ideas, predicament brought by stage fright, shortfall of vocabularies, } \\ & \text { insufficiency of terms, hurdles with difficult words, struggles on how to pronounce } \\ & \text { words correctly, problems with sentence construction, lack of mastery of the rules of } \\ & \text { subject-verb agreement, experiencing uneasiness through physical reactions, and } \\ & \text { exhibiting anxiousness through physical activities/discomfort. It is recommended that } \\ & \text { the proposed instructional material should be utilized to aid the needed speaking } \\ & \text { competence. }\end{array}$

\section{INTRODUCTION}

The English language is mainly used as a primary tool of communication and instruction by the majority worldwide, and consequently, it plays a vital role. Ardiansyah and Djohar (2012) noted that all work fields, English mastery has always been a requirement, and most documents and data are served in English due to globalization's effect. Furthermore, Zawahreh (2012) asserted that English is the foremost prominent language among the languages in the world since it's generally employed in various professions and businesses, including politics, science, the arts, tourism, and economics.

Thus, there is a need to intensify the importance of honing English language competence among learners to support the above claims. Pangket (2019) declared that though exposure to the English language is evident among Filipinos, they still have difficulty advancing their English language proficiency, particularly their oral communication skill. 

Globally, Hseih and Wang (2019) explored young language students' speaking proficiency. The study unveiled that the participants acquired sufficiency in fluency, grammatical rules, and vast vocabulary knowledge. These results confirm that the essential elements of speaking proficiency among young language students are fluency, grammar, vocabulary, and content.

In the Philippines, Gomez (2019) investigated pre-service teachers' oral proficiency assessment. Findings reveal that the participants rarely encounter difficulties using English when communicating, particularly in small groups, in front of a crowd, answering questions, explaining a written text, presenting lessons, entering discussions, presenting lectures, and interviewing. Also, they rarely worry about committing mistakes. However, they frequently have trouble when responding to impromptu questions.

In Tagum City, exposure to the English linguistic environment and oral proficiency was studied by Pascual (2019). The results showed that the student's level of exposure to their English linguistic environment is moderate However, they yielded low levels in vocabulary, comprehension, fluency, and grammar. Also, the result implied that the students' oral performance was adequate.

Despite the intervention programs that the teachers are administering, the insufficiency of speaking competence among students is still apparent. Specifically, in the non-sectarian university committed to democratizing access to education, there is no existing speaking intervention program or instructional material that focuses on enhancing students' oral language proficiency, specifically in the Purposive Communication course.

Moreover, the researcher observed that students' low self-confidence was due to a lack of exposure to speaking activities. Thus, to design the best fit material to help students attain the needed competency in speaking, this study was conceived. Also, this will serve as supplementary material to the course, which the researcher believed would help students achieve the needed self-confidence. Hence, the result of this study may serve as an additional input to the rising problem of second language competence among learners.

More importantly, the study results would benefit society, considering that oral language proficiency is essential in science and technology. The higher demand for speaking skills confirms the need for more effective and lifechanging teaching approaches. Moreover, the developed material intended for the learners is believed to enhance students' proficiency in speaking English. The study will help the researcher uncover the critical areas in the educational process that many could not explore.

\section{LITERATURE REVIEW}

\section{Oral Proficiency}

Iwashita (2010) asserted that previous studies on oral proficiency revealed that the factors contributing to second language proficiency remained unclear. Still, several studies showed that vocabulary and grammar were the most critical elements that ought to impact oral proficiency throughout the levels. Additionally, Iwashita (2010) suggested that these elements are vital to improving the learners' speaking competency.

Further, Iwashita, Brown, McNamara, and O'Hagan (2008) studied the nature of speaking proficiency in English as a second language to develop a rating scale. It revealed that each category's features improved distinguish overall performance levels, primarily in vocabulary and fluency.

Similarly, Larsen-Freeman (2006) analyzed the oral and written data of five Chinese learners. They primarily investigated their proficiency development by considering complexity, fluency, accuracy. The results disclosed that the participants acquired fluency, accuracy, and complexity of the language; however, each category needs improvement. 


\section{The Constructs of Oral Proficiency}

Spolsky and Hult (2008) claimed that linguistic problems (vocabulary, grammar, and pronunciation) contribute to poor speaking ability among learners. Moreover, the present study includes comprehension, fluency, and non-verbal communication, contributing to students' difficulty in speaking. Thus, various literature reviews are presented to give a foundation to this research.

\section{Comprehension}

Nadig (2013) declared that good listening comprehension is deemed important in understanding and making meaning of the spoken language. This includes identifying the syntax of the sentences, speech sounds and grasping the meaning of individual words. Hamouda (2013) postulated that good listening comprehension

enables learners to recognize and repeat the text. Also, O'Malley, Chamot, and Kupper (1989 cited in Pourhossein Gilakjani \& Ahmadi, 2011) declared the significance of listening comprehension. They posited an active process where the learner creates meaning from contextual information and prior knowledge to perform the task requirement.

\section{Fluency}

Lennon (2000) attested that oral proficiency is based on the listener's intuition rather than measurements utilizing proficiency tests. Lennon (2000) further declared that verbal fluency is the ability of the speaker to catch the audience's attention through presentation and asking questions.

Hughes (2002) supported that fluency is the capacity of the speaker to speak clearly to maintain the audience's focus. Meanwhile, Hedge (2000) proved that fluency aids coherently by being able to connect words and phrases, pronounce the sounds clearly, and use appropriate stress and intonation.

Oral fluency has a unique feature that enables the speaker to speak spontaneously with appropriate pausing, error-free, and a wide array of vocabulary knowledge (Polyakov and Tormyshova, 2014).

Lennon (2000) affirmed that fluency is measured either instrumentally or impressionistically. To attain this, consideration of speech rate and dysfluency markers is necessary. Also, fluency can be associated with smooth, precise, clear, and effective transitions of ideas. This definition fits well for the present study as it focuses on fluency.

There are three aspects of fluency claimed by (Ginther, Dimova, \& Yang, 2010; Kormos \& Dénes, 2004); (Ginther et al., 2010); (Iwashita, Brown, McNamara, \& O’Hagan, 2008). These include breakdown fluency, speed fluency, and repair fluency, respectively.

Ginther et al. (2010) and Kormos and Dénes (2004) argued that speech rate strongly predicts L2 fluency. (Ginther et al., 2010; Towell, Hawkins, \& Bazergui, 1996)'s mean length of run, (Kormos \& Dénes, 2004)'s word stress, filled or unfilled pauses, repairs, and repetition are related to fluency. Moreover, oral fluency is linked to speech flow, continuity, automaticity, or smoothness (Koponen \& Riggenbach, 2000).

Meanwhile, some authors like Dotan-Eliaz (2008) examined the relationship between speaking and fluency. It exhibited that good fluency isn't about uttering a language but higher conversation and conveyance of thoughts. For instance, students at different levels could elevate the necessary vocabulary to converse in another language.

\section{Vocabulary}

Vocabulary is a sufficiency of words used by learners (Graves, 2000, cited in Taylor, 1990). Additionally, vocabulary is the understanding of words and meanings (Diamond \& Gutlogn, 2006). This claim supports Stahl (2005)'s notion that vocabulary knowledge is a mastery of something and grows and intensifies throughout a lifetime.

Rohmatillah (2017) asserted that communication in second language acquisition becomes problematic without knowledge of the vocabulary. Additionally, it is fundamental to communicative competence and is an 
indispensable part of the language. On the other hand, Alqahtani (2015) highlighted that having insufficiency in vocabulary knowledge can impede the mastery of the English language, thus posing a severe problem to its learners.

Schmitt (2002) demonstrated that to communicate precisely, vocabulary knowledge is significant for a better mastery of L2. In a similar vein, human language depends upon vocabulary used and gained (Richards \& Renandya, 2002). Also, it deters the learners from using the language without adequate vocabulary knowledge. Hiebert and Kamil (2005) refer to vocabulary as learners' knowledge of the meaning of words. They also claimed that words could be oral and print. Knowledge is receptive when there is understanding or recognition and productive when one knows how to write or speak. Substantially, when learners know the meanings of the set of words while speaking or reading orally, it refers to oral vocabulary. In contrast, it is print vocabulary when the learners understand the meanings of the words when writing and reading quietly. Learners use productive vocabulary in speaking or writing, while they use receptive vocabulary in listening or reading when assigning meanings (Hiebert \& Kamil, 2005).

There are two types of vocabulary - active and passive (Harmer, 2007). The former is about teaching words to students and using them for speaking or writing. Whereas the latter is about relating the terms and understanding them in context for listening or reading material.

Vocabulary is expressive when the learner knows the relationship of the words and their meaning; and language is receptive when the learner has good listening for an acceptable interaction (Neuman \& Dwyer, 2009).

Elttayef and Hussein (2017) examined teachers' difficulties in teaching English among Arab learners. It disclosed that although participants are taught English in schools, they still have inadequate fundamental knowledge. Hence, teachers lacked highlighting the significance of using English in the classrooms. It is suggested that teachers should therefore maximize their role in the teaching process. Moreover, these learners encounter challenges when communicating, listening, and highlighting problems linked with teachers and curricula (Elttayef \& Hussein, 2017).

Farjami and Aidinlou (2013) claimed that it requires a high number of words. To retain long-term memory of learning a foreign or second language, learners make an effort to keep these words. This study also refines the learners' vocabulary problems and teachers' effective strategies to repair these problems. Farjami and Aidinlou (2013) recommended a practical approach to acquiring adequate vocabulary knowledge for such reasons. Thus, introducing a new set of words is affluent sufficient to find out meanings.

\section{Pronunciation}

Gilakjani (2012) declared that the essential requirement for a learner's competence is good pronunciation. Learning occurs when there's good pronunciation. On the contrary, incorrect pronunciation fosters exquisite difficulties in language learning. Besides, good pronunciation produces good sounds (Richard \& Schmidt, 2002).

Hinkel (2005) postulated acquiring unique characteristics of sounds is crucial for second language learners. Furthermore, speaking like native speakers is recommended for the students. James (2010) clarifies important points for acceptable pronunciation. For instance, when the speaker's message is unclear. Also, when uttering English words, the speaker uses incorrect sounds or incorrect prosodic features when creating English sentences. Additionally, James (2010) argued that to have attained the native-like accent is the target goal of studying pronunciation for some learners.

Hismanoglu (2006) argued that though pronunciation instruction is a source of communicative competence, it is crucial for successful communication. However, many teachers are no longer paying attention to teaching pronunciation skills regardless of the critical role in the English language. Some researchers have exemplified the problems of pronunciation instruction.

Harmer (2001) confirmed that little attention is given to the teaching of pronunciation by many teachers. Also, the learners are not paying attention to learning pronunciation. Additionally, nothing else is essential as long as they are understood when communicating the language.

Moreover, Harmer (2001) concluded that the utmost reasons teachers are not paying attention to English pronunciation are quality, practical teaching and instructional materials, and insufficient practice. Teachers assume that teaching pronunciation instruction is a waste of time and may add workload to them.

What a native speaker usually sees in communication is pronunciation (Harmer, 2001). Also, vocabulary and 
grammar are significant factors in language learning. Any native speaker can still understand learners who can pronounce accurately despite grammar lapses - correct pronunciation results in effective communication.

In Sudan University of Science and Technology, Hassan and Hassan (2007) explored English language learners' pronunciation problems. It revealed pronunciation problems such as interference, two languages' variation in sound system, and inconsistency of English sounds.

\section{Grammar}

Various researchers propose different definitions of grammar. In the description furnished by Celce-Murcia, Brinton, and Snow (2014), grammar relates to sounds, words, and their meaning. They claimed two kinds of grammar - prescriptive, descriptive, and pedagogical grammar. Prescriptive focuses on grammar rules, while the descriptive concentrates on grammar in daily use.

Moreover, Celce-Murcia et al. (2014) hinted that descriptive grammar describes how speakers use the language, even when it does not correspond to what prescriptive grammars prescribe and proscribe. On the other hand, pedagogical grammar is about grammar rules for instruction.

As Penny (2002) supported, to form more meaningful sentences, grammar manages and connects words. This notion leads to discussing grammar's two crucial principles: representational and interpersonal meanings.

In representational meaning, grammar allows language to express when, where, and how something happens. Meanwhile, in interpersonal, grammar aids how people interact with others using the language (Thornbury, 2006). Similarly, most dictionaries often present grammar as combining words to create sentences (Swan, 2005). Thus, Huang (2010) affirmed that mastery of grammar rules means using words more precisely and consciously.

Therefore, Azar (2007) reasoned that the language would become a batch of words if students do not have mastery of grammar rules since this permits them to explore the sets of patterns. In addition, they can use the language as much as they like if there is a complete mastery of grammar rules.

\section{Non-verbal Communication}

Negi (2009) associates non-verbal communication with the use of gestures, facial expressions, and others. This type of communication incites meaning in the mind of the listeners.

Likewise, Asubiojo, Adewusi, and Oyediran (2005) explain that non-verbal communication does not include words but is expressed in other methods, like using parts of the body's attitudes or actions rather than actions words. It takes place intentionally and unintentionally.

Non-verbal communication has three forms (Buck, 2001). Shaking hands, gestures, facial expressions, and body movements are actions that commonly occur in certain social situations. In short, non-verbal cues support a speaker in delivering messages effectively.

Non-verbal communication happens unintentionally. People become unaware of how effective non-verbal gestures are to help convey clear messages. These non-verbal cues support providing essential information to the audience (Haneef, Faisal, \& Zulfiqar, 2014).

Given (2002) stated that non-verbal communication such as postures and body movement influence mood and motivation. In its broadest sense, symbol, cue, and signal are used to communicate in addition to or instead of words. Face expressions, wardrobe clues, and bodily movements are all examples of gestures.

Butt (2011) declared that nonverbal communication is a transfer of meaning with no verbal symbols. In a literal sense, nonverbal communication refers to behaviors, objects, and settings that either convey directly or assist communication without words.

According to Bovee, Thill, and Barbara (2003), people's behaviors often speak louder than their words. Most people are considerably better at deceiving others with their words than they are with their bodies. Body language, facial expressions, and vocal qualities are more difficult to manage. As a result, observing these nonverbal indicators can help you spot dishonesty or confirm a speaker's honesty.

Phutela (2015) argued that a critical function of non-verbal communication is to communicate thoughts and produce a more appealing and fascinating message to the person listening. Similarly, Cenere, Gill, Lawson, and Lewis (2016) argued that a public speaker's non-verbal communication abilities properly conjoin the non-verbal communication message with the verbally communicated message inside a speech would boost the audience's trust and rapport. As a result, the audience will be perplexed by what the speaker is saying, despite these nonverbal communication forms being critical to public speaking success. 


\section{RESEARCH QUESTIONS}

This study intended to determine the perceived level of oral language proficiency and the challenges experienced by the students in speaking. It specifically sought answers to the following questions:

1. What is the perceived oral language proficiency level of the student respondents in terms of:
a) comprehension;
b) fluency;
c) vocabulary;
d) pronunciation;
e) grammar;
f) non-verbal communication;

2. What are the challenges experienced by the students during speaking activities in terms of:
a) comprehension;
b) fluency;
c) vocabulary;
d) pronunciation;
e) grammar;
f) non-verbal communication;

3. What instructional material design is appropriate for the development of an instructional material for Purposive Communication students?

4. What instructional material could be developed to enhance the speaking skill of the students taking Purposive Communication?

\section{METHODOLOGY}

\section{Research Design}

The present study used embedded mixed methods research design. Creswell and Clark (2010) asserted that the researcher employs a typical quantitative or qualitative research design to combine quantitative and qualitative data collection and analysis. The secondary data set may be collected and analyzed before, during, or after the data gathering and analysis techniques generally associated with the more significant design are implemented. This design is advantageous when a researcher embeds a qualitative component within a quantitative procedure, such as in an experimental or correlational design.

Cameron (2015) depicted this design as a study design based on philosophical assumptions and inquiry procedures. She claims that this design contains profound ideas that guide data collecting, analysis, and combining qualitative and quantitative data in a single study or series of studies.

As Johnson and Turner (2003) argued, the essential idea of mixed methods is learning the strengths and shortcomings of quantitative and qualitative research methodologies. Creswell (2012) supports that this strategy allows for a better grasp of the study problem.

Hence, the researcher embarks on the embedded mixed method by primarily using quantitative data collection through a survey questionnaire in examining students' perceived level of oral language proficiency. On the other hand, qualitative data collection will supplement the results by conducting a focus group discussion (FGD) in determining students' challenges in a speaking activity.

\section{Research Participants}

The research was confined to a private university where the researcher is employed. Four sections of first-year college students formally enrolled in Purposive Communication in the second semester of 2019-2020 participated in the study. The researcher chose 15 students at random to complete the survey questionnaire on oral language proficiency in each section. The quantitative data was collected from a total of 60 respondents.

On the other hand, the researcher chose two participants at random in each section because the study also utilized a qualitative research design to determine the participants' speaking issues. As a result, eight students took part in the focus group discussion three times in total. Participant 1 (P1) was a male accountancy student; participant 2 (P2) was a male criminology student; participant $3(\mathrm{P} 3)$ was a male civil engineering student; participant 4 (P4) was a male political science student; participant 5 (P5) and participant 6 (P6) were both female 
nursing students; participant 7 (P7) was a female civil engineering student; finally, participant 8 (P8) was a male criminology student.

\section{Sampling Design}

The researcher used a simple random sampling strategy to choose the participants. According to Popoola (2011), in simple random sampling, every member of the population has an equal probability of being selected for research. It is a method that assigns a non-zero chance of selection to each member of the population. When the population has similar features (homogeneous population), the sample frame is available, and the population size is fixed or finite, this sampling strategy is applied. Voting, a database of random numbers, and computer simulation can all be used to pick samples.

Along this line, Sanchez, Lai, and Fayad (2003) disputed that random sampling is a sampling strategy in which a set of individuals is chosen for a study to reflect a wider demographic group. The subject is picked at random and has an equal probability of participating in the study. Every sample of a specific size has the same chance of being chosen.

In the present study, the researcher used simple random sampling with four sections. In each class, 15 students were chosen at random, resulting in 60 respondents for quantitative data collection and eight for qualitative data collection.

\section{Research Instruments}

In quantitative data collection, the researcher used the Student Oral Language Observation Matrix (SOLOM) from 1978, as Gomez (2019) adopted. It assesses oral language proficiency on five levels: comprehension, fluency, vocabulary, pronunciation, and grammar.

Conversely, Gomez (2019) investigated pre-service teachers' oral proficiency assessment. She added two additional factors, such as classroom teaching and non-verbal communication, to measure their proficiency. However, in this present study, the researcher did not include classroom teaching as one of the indicators for oral language proficiency, considering its type of study and respondents. Consequently, the researcher adopted the instrument mentioned above to measure students' perceived level of oral language proficiency in purposive communication. The instrument has six constructs: comprehension, fluency, vocabulary, pronunciation, grammar, and non-verbal communication. The panel members approved the adopted instrument and was carefully examined by three expert validators for validity purposes.

In analyzing the perceived level of Oral Language Proficiency of the respondents, the following rating scale has been used:

\begin{tabular}{|c|c|c|}
\hline Range & $\begin{array}{c}\text { Verbal } \\
\text { Description }\end{array}$ & Interpretation \\
\hline $\begin{array}{l}4.21- \\
5.00\end{array}$ & $\begin{array}{l}\text { Strongly } \\
\text { Agree }\end{array}$ & $\begin{array}{l}\text { The participants' } \\
\text { perceived level of } \\
\text { oral language } \\
\text { proficiency is very } \\
\text { high. }\end{array}$ \\
\hline $\begin{array}{l}3.41- \\
4.20\end{array}$ & Agree & $\begin{array}{l}\text { The participants' } \\
\text { perceived level of } \\
\text { oral language } \\
\text { proficiency is high. }\end{array}$ \\
\hline $\begin{array}{l}2.61- \\
3.40\end{array}$ & Undecided & $\begin{array}{l}\text { The participants' } \\
\text { perceived level of } \\
\text { oral language }\end{array}$ \\
\hline
\end{tabular}


proficiency is

moderate.

1.81- Disagree The participants'

2.60 perceived level of

oral language

proficiency is low.

1.00- Strongly The participants'

1.80 Disagree perceived level of

oral language

proficiency is very

low.

Consequently, the study used focus group discussion (FGD) to determine the challenges and difficulties students faced in classroom speaking exercises to validate quantitative results. Hence, it aimed to gather in-depth responses from the participants. Wong (2008) declared that FGD is a methodological process that gathers a small group of participants to discuss a specific topic or issue to generate information. Also, for validity purposes, the instrument was carefully examined by three expert validators.

\section{RESULTS AND DISCUSSIONS}

This chapter unfolds the perceived level of the first-year Purposive Communication students concerning their oral language proficiency. This section also features the students' shared and lived experiences, challenges, and difficulties in learning the English language.

\section{Perceived Level of Oral Language Proficiency}

Table 1.

Perceived Level of Oral Language Proficiency

\begin{tabular}{lccc}
\hline \multicolumn{1}{c}{ Items } & $\begin{array}{c}\text { Standard } \\
\text { Deviation }\end{array}$ & Mean & $\begin{array}{c}\text { Verbal } \\
\text { Description }\end{array}$ \\
\hline COMPREHENSION & 0.61 & 3.80 & Agree \\
\hline FLUENCY & 0.70 & 3.49 & Agree \\
\hline VOCABULARY & 0.56 & 3.33 & Undecided \\
\hline PRONUNCIATION & 0.72 & 3.66 & Agree \\
\hline GRAMMAR & 0.65 & 3.46 & Agree \\
\hline NON-VERBAL COMMUNICATION & 0.89 & 3.68 & Agree \\
\hline Overall Standard Deviation/Mean & 0.69 & 3.57 & Agree \\
\hline
\end{tabular}

Legend:

$4.21-5.00=$ Strongly Agree

$3.41-4.20=$ Agree

$2.61-3.40=$ Undecided

$1.81-2.60=$ Disagree

$1.00-1.80=$ Strongly Disagree

Table 1 presents the perceived level of oral language proficiency of the first-year purposive communication students in six categories: namely comprehension, fluency, vocabulary, pronunciation, grammar, and nonverbal communication. It can be gleaned that the participants obtained an overall mean of $3.57(\mathrm{SD}=0.69)$, which indicates a description of Agree. The result revealed that the participants' perceived level of oral language 
proficiency is high. In brief, each indicator yielded the same description of Agree excepting vocabulary that designates a description of Undecided. This only suggests that the participants' perceived level of oral language, particularly in vocabulary, is moderate.

\section{Challenges Experienced by the Students During Speaking Activities}

Challenges in terms of Comprehension. The interview transcriptions produced comprehension-related challenges that hindered the participants from communicating the English language correctly. The major themes that emerged in comprehension are dilemmas in comprehending the subject matter/topic and drawbacks in analyzing the question. Hence, these themes in comprehension served as the basis for the discussion. Table 2 presents the themes on challenges in terms of comprehension.

\section{Table 2}

Themes on challenges in terms of comprehension

Theme 1 $\quad$ Dilemmas in Comprehending the Subject Matter/Topic

Theme 2 Drawbacks in Analyzing the Question

Challenges in terms of Fluency. The results of the interview transcriptions produced fluency-related challenges that impede the participants in communicating the English language spontaneously. The difficulties experienced by the students in terms of fluency are troubles in organizing thoughts and ideas and predicament brought by stage fright. Hence, these challenges served as the basis for the discussion. Table 3 presents the themes on the challenges in terms of fluency.

\section{Table 3}

Themes on challenges in terms of fluency

\begin{tabular}{|l|l|}
\hline Theme 1 & Troubles in Organizing Thoughts and Ideas \\
\hline Theme 2 & Predicament brought by Stage Fright \\
\hline
\end{tabular}

Challenges in terms of Vocabulary. The narratives from the participants revealed vocabulary-related challenges that hampered them in every speaking activity. These challenges in vocabulary are shortfall of vocabularies and insufficiency of terms. Hence, these themes served as the basis for the discussion. Table 4 presents the themes on the challenges in terms of vocabulary.

\section{Table 4}

Themes on challenges in terms of vocabulary

\begin{tabular}{|l|l|}
\hline Theme 1 & Shortfall of Vocabularies \\
\hline Theme 2 & Insufficiency of Terms \\
\hline
\end{tabular}

Challenges in terms of Pronunciation. The FGD results revealed challenges in pronunciation that the participants experienced during their speaking activities. The pronunciation-related themes that flourished are hurdles with difficult words and struggles on how to pronounce words correctly. Thus, these challenges served as the basis for the discussion. Table 5 presents the themes on the challenges in terms of pronunciation.

\section{Table 5}

Themes on challenges in terms of pronunciation

\begin{tabular}{|l|l|}
\hline Theme 1 & Hurdles with Difficult Words \\
\hline Theme 2 & Struggles on how to Pronounce Words Correctly \\
\hline
\end{tabular}

Challenges in terms of Grammar. The narratives from the participants revealed grammar-related challenges that also obstructed the participants from communicating the English language appropriately. The themes that emerged in grammar are problems with sentence construction and lack of mastery of the rules of subject-verb agreement. Hence, these challenges served as the basis for the discussion. Table 6 presents the themes on the challenges in terms of grammar. 


\section{Table 6}

Themes on challenges in terms of grammar

\begin{tabular}{|l|l|}
\hline Theme 1 & Problems with Sentence Construction \\
\hline Theme 2 & Lack of Mastery of the Rules of Subject-Verb Agreement \\
\hline
\end{tabular}

Challenges in terms of Non-Verbal Communication. The participants' narratives revealed challenges related to non-verbal communication that baffled them from using the English language correctly. Based on the thematic analysis, the themes flourished in terms of this construct are experiencing uneasiness through physical reaction and exhibiting anxiousness through physical activities/discomfort. Hence, these challenges in non-verbal communication served as the basis for the discussion. Table 7 presents the themes in non-verbal communication.

\section{Table 7}

Themes on challenges in terms of non-verbal communication

\begin{tabular}{|l|l|l|}
\hline Theme 1 & Experiencing Uneasiness through Physical Reactions \\
\hline Theme 2 & $\begin{array}{l}\text { Exhibiting Anxiousness through Physical } \\
\text { Activities/Discomforts }\end{array}$ & \\
\hline
\end{tabular}

\section{CONCLUSIONS}

The study examined the college students' perceived level of oral language proficiency and determined the challenges encountered in speaking activities. It employed an embedded mixed-method design where an adopted survey questionnaire contained six constructs of oral language proficiency: comprehension, fluency, vocabulary, pronunciation, grammar, and non-verbal communication. The study involved 60 first-year college students taking purposive communication in a private university in Davao City. However, in qualitative data collection, it only selected eight respondents to participate in the interview sessions.

The quantitative results revealed that the participants' overall perceived level of oral language proficiency is high. In particular, comprehension is high; non-verbal communication is high; pronunciation is high; fluency is high; grammar is high, and vocabulary is moderate.

Subsequently, the FGD sessions revealed significant themes in each construct. These themes were categorized accordingly. First, comprehension themes are dilemmas in comprehending the subject matter/topic and drawbacks in analyzing the question. Next, fluency themes are troubles in organizing thoughts and ideas and predicament brought by stage fright. Subsequently, vocabulary themes are shortfall of vocabularies and insufficiency of terms. Then, pronunciation themes are hurdles with difficult words and struggles on how to pronounce words correctly. Meanwhile, the grammar themes are problems with sentence construction and a lack of mastery of subject-verb agreement. Finally, non-verbal communication themes are experiencing uneasiness through physical reactions and exhibiting anxiousness through physical activities/discomfort.

Therefore, there is a need to pay attention to the challenges experienced by the students in oral activities. These speaking challenges are considered detrimental factors that impede to use of the target language effectively. Thus, addressing this concern will achieve the needed speaking competence of the English language. The researcher believed that the PPP (practice, presentation, production) method would be an appropriate design for material development. Finally, the instructional material developed by the researcher would help enhance the speaking skills of the students.

\section{REFERENCES}

Alqahtani, M. (2015). The importance of vocabulary in language learning and how to be taught. International Journal of Teaching and Education, 3(3), 21-34.

Allen, D., \& Tanner, K. (2003). Approaches to cell biology teaching: Learning content in context-problembased learning. Life Sciences Education, 2(2), 73-81.

Ardiansyah, W. \& Djohar, A. (2012). Development of reading learning model to improve reading 
comprehension skill in learning English: Studies on Polytechnic students in Palembang. Ta'dib: Journal of Islamic Education, 17(2), 161-167. Retrieved from https://cutt.ly/puVNr3a

Asubiojo, E., Adewusi, C., \& Oyediran, A. (2005). Communication theory and practice. Ibadan: Aseda Publisting.

Azar, B. (2007, September). Grammar-based teaching: A practitioner's perspective. TESL-EJ: Teaching English as a Second or Foreign Language, 11(2), 1-12.

Bovee, L., Thill, V., \& Barbara, E. (2003). Business communication today. (7th ed.). New Jersey, USA: Prentice Hall.

Buck, G. (2001). Assessing listening. Cambridge, UK: Cambridge University Press.

Butt, M. (2011). Impact of non-verbal communication on students' learning outcomes (Doctoral dissertation, Sarhad University of Science and Information Technology, Peshawar-Pakistan).

Cameron, R. (2015, July 2). Mixed methods research. Retrieved from Deakin University: https://cutt.ly/ofKa4gr

Celce-Murcia, M., Brinton, D., \& Ann Snow, M. (2014). Teaching English as a second or foreign language (4th ed.). UK: Heinle Cengage Learning.

Cenere, P., Gill, R., Lawson, C., \& Lewis, M. (2016). Communication skills for business professionals. Port Melbourne: Cambridge University Press.

Creswell, J. (2012). Educational research: planning, conducting, and evaluating quantitative and qualitative research (4th ed.). Boston: Pearson.

Creswell, J., \& Clark, V. (2010). Designing and conducting mixed methods research (2nd ed.). Thousand Oaks, California: SAGE Publications, Inc.

Diamond, L. \& Gutlohn, L. (2006). Teaching vocabulary. Retrieved September 20, 2009, from https://cutt.ly/ruVMtEi

Dotan-Eliaz, O. (2008). Working in multilingual settings: The impact of speaking a lower-fluency language on bilinguals' self-regulation. City University of New York.

Ellis, R. (2003). Task-based language learning and teaching. Oxford: Oxford University Press.

Elttayef, A., \& Hussein, N. (2017). Arab learners' problems in learning English language: A teacher perspective. Journal of Literature, Languages and Linguistics, 40, 1-6.

Farjami, F., \& Aidinlou, N. (2013). Analysis of the impediments to English vocabulary learning and teaching. International Journal of Language and Linguistics. Special Issue: Language Teaching and Learning Key Principles (LTLKP), 1(4-1), 1-5.

Freeman, S., O’Connor, E., Parks, J., Cunningham, M., Hurley, D., Haak, D., \& Wenderoth, M. (2007). Prescribed active learning increases performance in introductory biology. CBE-Life Sciences Education, 6(2), 132-139.

Gomez, A. (2019). Oral proficiency assessment of pre-service teachers of a public University in the Philippines. The ASTR Research Journal, 1(1). Retrieved from https://cutt.ly/zuVMWNG

Gilakjani, A. (2012). A study of factors affecting EFL learners' English pronunciation learning and the strategies for instruction. International Journal of Humanities and Social Science, 2(3), 119-128.

Ginther, A., Dimova, S., \& Yang, R. (2010). Conceptual and empirical relationships between temporal measures of fluency and oral English proficiency with implications for automated scoring. Language Testing, 27, 379-399.

Given, D. (2002). The nonverbal dictionary of gestures, signs \& body language cues. Washington: Centre for nonverbal studies press. Retrieved May 26, 2010, from https://cutt.ly/luBEkOI

Graves, M. (2000). A vocabulary program to complement and bolster a middle-grade comprehension program. In B. Taylor, M. Graves, and P. Van Den Broek (Ed.). Reading for meaning: Fostering comprehension in the middle grades, New York: Teachers College Press.

Hamouda, A. (2013). An investigation of listening comprehension problems encountered by Saudi students in the EL listening classroom. International Journal of Academic Research in Progressive Education and Development, 2(2), 113-155.

Haneef, M., Faisal, M., \& Zulfiqar, M. (2014). The role of non-verbal communication in teaching practice. Sci. Int. (Lahore), 26(1), 513-517.

Harmer, J. (2001). The practice of English language teaching. London: Longman.

Harmer, J. (2007). The practice of English language teaching. Harlow: Pearson Longman.

Harmer, J. (2009). How to teach (5th ed.). Harlow: Longman. 
Hassan, E., \& Hassan, S. (2007). Pronunciation problems. A case study of English language students at Sudan University of Science and Technology (Doctoral dissertation, Sudan University of Science and Technology).

Hedge, T. (2000). Teaching and learning in the language classroom. Oxford: Oxford University Press.

Hiebert, E., \& Kamil, M. (2005). Teaching and learning vocabulary: Bringing research to practice. New Jersey, NY: Lawrence Erlbaum Associates.

Hinkel, E. (2005). Handbook of research in second language teaching and learning. London: Seattle University.

Hismanoglu, M. (2006). Current perspectives on pronunciation learning and teaching. Journal of Language and Linguistic Studies, 2(1), 101-110.

Hsieh, C., \& Wang, Y. (2019). Speaking proficiency of young language students: A discourse-analytic study. Language Testing, 36(1), 27-50.

Huang, J. (2010). Grammar instruction for adult English language learners: A task-based learning framework. Journal of Adult Education, 39. Retrieved November 1, 2010

Hughes, R. (2002). Teaching and researching speaking. New York: Pearson Education.

Iwashita, N., Brown, A., Mcnamara, T., \& O'Hagan, S. (2008). Assessed levels of second language speaking proficiency: How distinct? Applied Linguistics, 29(1), 24-49.

Iwashita, N. (2010). Selected proceedings of the 2008 second language research forum. In M.T. Prior et al (Ed.). (pp. 32-47). Somerville, MA: Cascadilla Proceedings Project.

James, R. (2010). Teaching pronunciation gets a bad R.A.P: A framework for teaching pronunciation. Hankuk: University of Foreign Studies.

Johnson, R., \& Turner, L. (2003). Data collection strategies in mixed methods research. In A. Tashakkori, \& C. Teddlie (Ed.), Handbook of mixed methods in social and behavioral research (pp. 297-319). Thousand Oaks, CA: Sage.

Koponen, M., \& Riggenbach, H. (2000). Overview: Varying perspectives on fluency. In H. Riggenbach (Ed.), perspectives on fluency (pp. 5-24). Ann Arbor, MI: University of Michigan Press.

Kormos, J., \& Dénes, M. (2004). Exploring measures and perceptions of fluency in the speech of second language learners. System, 32, 145-164.

Larsen-Freeman, D. (2006). The emergence of complexity, fluency and accuracy in the oral and written production of five Chinese learners of English. Applied Linguistics, 27(4), 590-619.

Lennon, P. (2000). The lexical element in spoken second language fluency. In H. Riggenbach, (Ed.), Perspectives on fluency (pp. 25-42). MI: The University of Michigan Press.

Merrill, M.D. (2002). Summary of first principles. [Online] Mdavidmerrill.com. Retrieved 19 January 2009, from https://cutt.ly/4uV123e

Michael, J. (2006). Where's the evidence that active learning works? Advances in Physiology Education, 30(4), $159-167$.

Nadig, A. (2013). Listening comprehension. Encyclopedia of autism spectrum disorders, 1743. Retrieved from https://cutt.ly/liMONX5

Negi, J. (2009). The role of teachers' non-verbal communication in ELT classroom. Journal of NELTA. 14(12), 101-110.

Neuman, S., \& Dwyer, J. (2009). Missing in action: Vocabulary instruction in Pre-K. The Reading Teacher, 62(5), 384-392.

O'Malley, J., Chamot, A., \& Küpper, L. (1989). Listening comprehension strategies in second language acquisition. Applied Linguistics, 10(4), 418-437.

Pangket, W. (2019). Oral English proficiency: Factors affecting the learner's development. International Journal of Science and Management Studies, 2(2).

Pascual, L. P. (2019). Exposure to English linguistic environment and oral proficiency of first year college students in Davao del Norte. In Proceedings of the $10^{\text {th }}$ International Conference on E-Education, EBusiness, E-Management and E-Learning (pp. 225-229).

Penny, U. (2002). Grammar practice activities: A practical guide for teacher. United Kingdom: Cambridge University Press.

Phutela, D. (2015). The importance of non-verbal communication. IUP Journal of Soft Skills, 9(4), 43-49.

Popoola, S. (2011). Research methodologies in library and information science. Covenant University, Ota, 
University: Nigerian Library Association.

Polyakov, O., \& Tormyshova, T.Y. (2014). Fluency of speaking in a foreign language as a linguomethodological issue. Language and Culture, 28, 166-174.

Pourhossein Gilakjani, A., \& Ahmadi, M. (2011). A study of factors affecting EFL learners' English listening comprehension and the strategies for improvement. Journal of Language Teaching and Research, 2(5), 977- 988.

Richards, J., \& Rodgers, T. (2001). Approaches and methods in language teaching. London: Cambridge University Press.

Richards, J., \& Schmidt, R. (2002). Dictionary of language teaching and applied linguistics (3rd ed.). London: Longman.

Richards, J., \& Renandya, W. (Eds.). (2002). Methodology in language teaching: An anthology of current practice. New York, NY: Cambridge University Press.

Rohmatillah, R. (2017). A study on students' difficulties in learning vocabulary. English Education: Jurnal Tadris Bahasa Inggris, 6(1), 75-93.

Sanchez, H., Lai, B., \& Fayad, M. (2003). The sampling analysis pattern. Proceedings Fifth IEEE Workshop on Mobile Computing Systems and Applications (pp. 601-608). IEEE.

Schmitt, N. (2002). Difficulties with vocabulary word form: The case of Arabic ESL learners. System, 40(1), 24-36.

Smith, A., Stewart, R., Shields, P., Hayes-Klosteridis, J., Robinson, P., \& Yuan, R. (2005). Introductory biology courses: A framework to support active learning in large enrollment introductory science courses. Life Sciences Education, 4(2), 143-156.

Spolsky, B., \& Hult, F. (2008). Introduction: What is educational linguistics? In B. Spolsky, \& F. Hult (Ed.), The handbook of educational linguistics (pp. 1-9). Malden, MA: Blackwell Publishing.

Stahl, S. (2005). Four problems with teaching word meanings and what to do to make vocabulary an integral part of instruction. In E. Hiebert, \& M. Kamil (Ed.), Teaching and learning vocabulary: Bringing research to practice. Mahwah, $\mathrm{NJ}$ : Erlbaum.

Swan, M. (2005). What is grammar? In B. Beaven (Ed.), IATEFL. Cardiff Conference Selections, (pp.60-61).

Taylor, L. (1990). Teaching and learning vocabulary. Herefordshire, UK: Prentice Hall International.

Thornbury, S. (2006). How to teach grammar. Malaysia: Pearson Education Limited.

Towell, R., Hawkins, R., \& Bazergui, N. (1996). The development of Fluency in advanced learners of French. Applied Linguistics, 17, 84-119.

Zawahreh, F. (2012). Applied error analysis of written production of English essays of tenth grade students in Aljouri Schools, Jordan. International Journal of Learning and Development, 2(2), 280-299 


\section{BIONOTE}

He holds an academic level of Associate Professor at the Languages Discipline, College of Arts and Sciences Education, University of Mindanao, teaching communication, arts, reading comprehension, and technical writing subjects. He has participated in various local and national seminars and workshops related to language and education and participated in research conferences. Presently, he is taking a Doctor of Philosophy in Applied Linguistics at the same university. 